Original Contribution

\title{
LABORATORY AND FIELD STUDIES ON ACUTE PHASE RESPONSE OF HORSES AFTER VACCINATION AGAINST EQUINE INFLUENZA VIRUS AND EQUINE HERPES VIRUS 4/1
}

\author{
D. Gundasheva ${ }^{*}$, I. Tsachev ${ }^{2}$ \\ ${ }^{1}$ Department of General and Clinical Pathology, Faculty of Veterinary Medicine, \\ Trakia University, Stara Zagora, Bulgaria \\ ${ }^{2}$ Department of Microbiology, Infectious and Parasitic Diseases, Faculty of Veterinary Medicine, \\ Trakia University, Stara Zagora, Bulgaria
}

\begin{abstract}
PURPOSE: The purpose of the present study was to evaluate the effects of booster vaccination of horses with multivalent vaccine against equine herpes virus $4 / 1$ and equine influenza virus (EIV) on some acute phase response indices - classical pathway of complement activation (CPCA), erythrocyte sedimentation rate (ESR) and some clinical parameters. METHODS: Nine Hanoverian geldings were divided into two groups: group A -3 non-vaccinated animals and group B -6 revaccinated animals. Horses from group B were vaccinated one year ago against EHV 4/1 and EIV. CPCA was assayed as per the method of Mayer, modified for horses and ESR - by the method of Westergren. Pulse rate (PR), respiratory rate (RR) and rectal temperature (RT) were also monitored throughout the 14-day experimental period. RESULTS: In horses from group B, a substantial increase in haemolytic activity of CPCA was established $(24-72 \mathrm{~h})$, enhanced ESR (by the $72^{\text {nd }} h$ ), accelerated PR by the $24^{\text {th }} \mathrm{h}$ within the reference range, no statistically significant changes in RR and absence of fever. CONCLUSIONS: The changes in acute phase response parameters CPCA, ESR, PR, RR and RT after revaccination of horses could provide information for their health status with respect to their performance and participation in competitions.
\end{abstract}

Key words: horses, EHV4/1/EIV vaccine, booster vaccination, complement, ESR, clinical parameters

\section{INTRODUCTION}

Vaccines are natural immune system stimulants aimed at active protection from infectious diseases. Although rarely, the simultaneous application of multivalent vaccines (which are more immunogenic than monovalent ones) could increase the risk of undesirable side effects (1). According to some authors, these vaccines could provoke adverse responses of different magnitude. Mild reactions as inflammation with swelling, pain and warmth at the site of intramuscular application (most often in the region of the neck), tenderness and difficult neck movement when a larger area is

\footnotetext{
*Correspondence to: Assoc. Prof. Dimitrina Gundasheva PhD, Department of General and Clinical Pathology, Faculty of Veterinary Medicine, Trakia University, Student's Campus, 6000 Stara Zagora, Bulgaria; phone 042699 580; e-mail: d_gundasheva@abv.bg
}

affected as well as abscesses have been reported (2). Moderate reactions - dyspnea, muscle oedema, stiffness (3) and acute-phase reactions - substantial increase in concentrations of serum amyloid A (4) and haptoglobin (5) were also demonstrated. Others provided evidence for milk fever, anorexia, lethargy, general discomfort over several days, or week or two (2) and purpura hemorrhagica (6). Severe responses - hypersensitivity reactions including fatal anaphylactic shock (7-8) and autoimmune diseases were occasionally established (9). All these data outline the importance of systemic homeostasis alterations in horses following vaccination, which is also of exceptional significance with regard to their sport performance and participation in races. Therefore, the purpose of the present study was to investigate some less common parameters of acute phase response as classical pathway of 
complement activation (CPCA) and erythrocyte sedimentation rate (ESR) together with clinical parameters which could provide information for the health status of jumping horses after application of multivalent vaccine against equine herpes virus (EHV4/1) and equine influenza virus (EIV).

\section{MATERIAL AND METHODS}

\section{1) Horses}

Nine healthy Hanoverian geldings, 6 to 9 years of age, weighing 500-600 kg, were included in the study. Horses were housed in the stalls of the Trakia University Experimental Equine Base in Stara Zagora. They were divided in two groups: group A consisting of 3 non-vaccinated horses serving as controls and group B -6 revaccinated horses, which were vaccinated against EHV4/1 and EIV a year ago. Revaccination was performed 14 days before the start of training.

Horses were reared in safe, hygienic and comfortable boxes under suitable environmental conditions - proper ventilation, optimum light and temperature regimen, fed commercial pelleted ration and alfalfa-grass hay. Salt and water were offered ad libitum. Care was provided by professional horse carers.

\section{2) Vaccination}

At the day of vaccination (i.e. revaccination as horses received a dose a year ago), and one week after being treated against parasites, horses from group B received a booster dose $(1 \mathrm{~mL})$ of oil adjuvant vaccine against influenza and rhinopneumonitis (Fluvac EHV 4/1 Plus, Fort Dodge, Iowa, USA) via aseptic intramuscular application in the neck. Controls (group A) were treated with equivalent volume of sterile physiological saline (placebo) using identical syringes.

All procedures and manipulations were compliant with Bulgarian legislation for animal welfare and protection.

\section{3) Blood samples}

Blood samples were obtained from $v$. jugularis externa in plain tubes. Samples were kept at room temperature for $2 \mathrm{~h}$ to coagulate and were then centrifuged at $1,200 \times g$ for $10 \mathrm{~min}$ at $4{ }^{\circ} \mathrm{C}$. Sera were used for CPCA determination.

For analysis of ESR, blood samples were anticoagulated with $3.8 \%$ sodium citrate. Data were obtained by detection of red blood cells settling after one hour. Both parameters were monitored initially, and post revaccination hours

\section{2, 24, 48, 72 and days 7 and 14 .}

4) CPCA assay

Classical pathway of complement activation was assayed by the method of Mayer (10), adapted for horses (11). Sheep red blood cells (RBC) were washed in veronal buffer to prepared 5\% suspension with optical density of 0.700 at wavelength $541 \mathrm{~nm}$. Sheep RBC were sensitised with rabbit anti-sheep haemolysin (National Centre of Infectious and Parasitic Diseases, Bulgaria), diluted $1 / 40$ in veronal buffer. The sheep RBC-antibody mixture was incubated in water bath at $37^{\circ} \mathrm{C}$ with frequent resuspending for $30 \mathrm{~min}$, followed by $30-\mathrm{min}$ cooling in ice.

For complement reaction, serial dilutions of horse serum in ice-cold veronal buffer were added with continuous swirling to sheep RBC suspension. Samples were incubated in water bath and often resuspended over an hour at $37^{\circ} \mathrm{C}$. Haemolytic reaction was stopped by 5 -min placement in ice bath followed by cooling centrifugation $\left(4^{\circ} \mathrm{C}\right)$ for $10 \mathrm{~min}$ at $500 \times \mathrm{g}$. Supernatants were analysed spectrophotometrically at $540 \mathrm{~nm}$ for quantitation of haemolysis. The lysis percentage was calculated and compared vs blank sample (sheep RBC in distilled water). Haemolytic activity of classical pathway of complement activation was presented as $50 \%$ haemolytic units (CH50). $\mathrm{CH} 50$ is reciprocal to tested serum dilution able to lyse $50 \%$ of sensitised sheep RBC.

5) ESR determination

ESR was determined by the method of Westergren recommended as a reference method by the International Committee on Standardisation in Hematology. Westergren glass pipettes were filled with blood and placed vertically in a special rack. During the assay, samples were kept at room temperature not higher than $25^{\circ} \mathrm{C}$.

6) Clinical studies

Horses were thoroughly monitored for presence of postvaccinal reactions throughout the entire experimental period - nasal discharge, cough, changes in submandibular lymph nodes, local inflammation responses at the site of injection (swelling, warmth, pain) and systemic manifestations - fever, lethargy, anorexia, hypersensitivity reactions - urticaria, anaphylaxis. Pulse rate, respiratory rate and rectal temperature were monitored.

7) Statistical analysis

The results were presented as mean (SE). 
Differences related to time course of studied parameters in revaccinated group were analysed by one-way ANOVA. Between-group differences were determined by the nonparametric Mann-Whitney U-test.

\section{RESULTS}

Horses from the control group (group A) did not exhibit any significant changes in complement haemolytic activity and ESR values. The pulse was strong and rhythmic, without significant deviations. Neither respiratory rate nor rectal temperature were changed (Table 1).

The haemolytic activity of complement in group B was statistically significantly higher on hour $24(p<0.01), 48$ and $72(p<0.05)$ vs the initial level, as well as on hour 2 vs group A ( $<<0.05)$. ESR of revaccinated horses was enhanced on hour 72 compared to values in control animals. Pulse rate was accelerated 24 hours after vaccination vs baseline $(\mathrm{p}<0.05)$ and on the $2^{\text {nd }}$ hour vs group A $(p<0.05)$, although it remained within the reference range. There were no statistically significant changes in respiratory rate and rectal temperature. No local signs of inflammation (pain, warmth, swelling) were observed at vaccination site. Only one horse exhibited a small non-painful plaque due to subcutaneous oedema at injection site on hour 24 , which was completely resolved after the $48^{\text {th }}$ hour. None of horses has shown lethargy, anorexia, or hypersensitivity reactions as urticaria or anaphylaxis. Nasal discharges, cough and changes in submandibular lymph nodes were not found (Table 1).

Table 1. Changes in classic pathway of complement activation (CPCA), ESR ( $\mathrm{mm} / \mathrm{h})$, pulse and respiratory rates and rectal temperature in group $A$ (control $n=3)$ and group $B($ revaccinated, $n=6)$.

\begin{tabular}{|c|c|c|c|c|c|c|c|}
\hline Indices & $\begin{array}{c}\text { Initial } \\
\text { level }\end{array}$ & $2 \mathrm{~h}$ & $24 \mathrm{~h}$ & $48 \mathrm{~h}$ & $72 \mathrm{~h}$ & $7 \mathrm{~d}$ & $14 \mathrm{~d}$ \\
\hline \multicolumn{8}{|c|}{ Group A (control) } \\
\hline $\begin{array}{l}\text { CPAC } \\
\text { (CH50) }\end{array}$ & $\begin{array}{l}19.83 \\
(1.17)\end{array}$ & $\begin{array}{l}19.1 \\
(0.3)\end{array}$ & $\begin{array}{c}21.7 \\
(1.05)\end{array}$ & $\begin{array}{l}21.02 \\
(0.77)\end{array}$ & $\begin{array}{c}21.5 \\
(1.01)\end{array}$ & $\begin{array}{l}21.15 \\
(0.74)\end{array}$ & $\begin{array}{l}21.45 \\
(0.73)\end{array}$ \\
\hline $\begin{array}{c}\text { ESR } \\
(\mathrm{mm} / \mathrm{h})\end{array}$ & $\begin{array}{c}66 \\
(7.21)\end{array}$ & $\begin{array}{c}68 \\
(5.69)\end{array}$ & $\begin{array}{c}72 \\
(7.21)\end{array}$ & $\begin{array}{l}71.33 \\
(9.04)\end{array}$ & $\begin{array}{l}64.67 \\
(5.49)\end{array}$ & $\begin{array}{c}75 \\
(7.64)\end{array}$ & $\begin{array}{c}73 \\
(6.25)\end{array}$ \\
\hline $\begin{array}{l}\text { Pulse rate } \\
\text { (/min) }\end{array}$ & $\begin{array}{l}31.33 \\
(0.88)\end{array}$ & $\begin{array}{l}31.67 \\
(0.33)\end{array}$ & $\begin{array}{l}33.67 \\
(1.20)\end{array}$ & $\begin{array}{c}32 \\
(2.31)\end{array}$ & $\begin{array}{l}32.33 \\
(2.19)\end{array}$ & $\begin{array}{l}31.67 \\
(0.67)\end{array}$ & $\begin{array}{l}34 \\
(1)\end{array}$ \\
\hline $\begin{array}{l}\text { Respiratory } \\
\text { rate }(/ \mathrm{min})\end{array}$ & $\begin{array}{l}15.33 \\
(1.86)\end{array}$ & $\begin{array}{c}16 \\
(0.58)\end{array}$ & $\begin{array}{c}15 \\
(0.58)\end{array}$ & $\begin{array}{l}15.67 \\
(1.2)\end{array}$ & $\begin{array}{l}15.33 \\
(1.2)\end{array}$ & $\begin{array}{l}15.67 \\
(0.33)\end{array}$ & $\begin{array}{c}16 \\
(1.73)\end{array}$ \\
\hline $\begin{array}{l}\text { Rectal } \\
\text { temperature } \\
\left({ }^{\circ} \mathrm{C}\right)\end{array}$ & $\begin{array}{l}37.93 \\
(0.03)\end{array}$ & $\begin{array}{l}37.7 \\
(0.1)\end{array}$ & $\begin{array}{l}37.77 \\
(0.07)\end{array}$ & $\begin{array}{l}37.77 \\
(0.15)\end{array}$ & $\begin{array}{l}37.93 \\
(0.45)\end{array}$ & $\begin{array}{l}37.77 \\
(0.22)\end{array}$ & $\begin{array}{l}37.77 \\
(0.26)\end{array}$ \\
\hline \multicolumn{8}{|c|}{ Group B (revaccinated) } \\
\hline $\begin{array}{l}\text { CPAC } \\
(\mathrm{CH} 50)\end{array}$ & $\begin{array}{l}20.02 \\
(0.54)\end{array}$ & $\begin{array}{c}20.66 \\
(0.47)^{1}\end{array}$ & $\begin{array}{c}23.58 \\
(1.38)^{\mathrm{b}}\end{array}$ & $\begin{array}{c}22.62 \\
(1.11)^{\mathrm{a}}\end{array}$ & $\begin{array}{l}21.55 \\
(0.5)^{\mathrm{a}}\end{array}$ & $\begin{array}{c}21.4 \\
(0.46)\end{array}$ & $\begin{array}{c}20.7 \\
(0.36)\end{array}$ \\
\hline $\begin{array}{c}\text { ESR } \\
(\mathrm{mm} / \mathrm{h})\end{array}$ & $\begin{array}{l}86.67 \\
(7.02)\end{array}$ & $\begin{array}{c}85.5 \\
(12.98)\end{array}$ & $\begin{array}{c}94.5 \\
(12.34)\end{array}$ & $\begin{array}{c}93.67 \\
(12.61)\end{array}$ & $\begin{array}{c}107.17 \\
(13.69)^{1}\end{array}$ & $\begin{array}{l}95.5 \\
(8.9)\end{array}$ & $\begin{array}{c}91 \\
(7.43)\end{array}$ \\
\hline $\begin{array}{l}\text { Pulse rate } \\
\text { (/min) }\end{array}$ & $\begin{array}{l}32.83 \\
(2.15)\end{array}$ & $\begin{array}{c}34.83 \\
(0.65)^{1}\end{array}$ & $\begin{array}{c}36.5 \\
(1.26)^{\mathrm{a}}\end{array}$ & $\begin{array}{l}34.33 \\
(1.09)\end{array}$ & $\begin{array}{c}31.5 \\
(0.92)\end{array}$ & $\begin{array}{l}31.83 \\
(0.65)\end{array}$ & $\begin{array}{l}32.33 \\
(0.76)\end{array}$ \\
\hline $\begin{array}{l}\text { Respiratory } \\
\text { rate }(/ \mathrm{min})\end{array}$ & $\begin{array}{l}15.83 \\
(1.01)\end{array}$ & $\begin{array}{l}18.83 \\
(1.68)\end{array}$ & $\begin{array}{c}20 \\
(1.71)\end{array}$ & $\begin{array}{c}16 \\
(0.89)\end{array}$ & $\begin{array}{l}13.33 \\
(1.02)\end{array}$ & $\begin{array}{c}14.5 \\
(2.45)\end{array}$ & $\begin{array}{l}15.67 \\
(0.95)\end{array}$ \\
\hline $\begin{array}{c}\text { Rectal } \\
\text { temperature } \\
\left({ }^{\circ} \mathrm{C}\right)\end{array}$ & $\begin{array}{l}38.03 \\
(0.06)\end{array}$ & $\begin{array}{l}37.97 \\
(0.09)\end{array}$ & $\begin{array}{l}38.03 \\
(0.11)\end{array}$ & $\begin{array}{c}38.17 \\
(0.1)\end{array}$ & $\begin{array}{l}37.92 \\
(0.16)\end{array}$ & $\begin{array}{l}37.87 \\
(0.15)\end{array}$ & $\begin{array}{l}38.02 \\
(0.14)\end{array}$ \\
\hline
\end{tabular}

Data are presented as mean (SE). Level of significance: ${ }^{a} \mathrm{p}<0.05 ;{ }^{b} \mathrm{p}<0.01$ vs initial level; ${ }^{1} \mathrm{p}<0.05 ;{ }^{2} \mathrm{p}<0.01$ between groups.

\section{DISCUSSION}

The vaccination provoked a marked inflammatory response with statistically significant increase in CPCA haemolytic activity during the first 72 hours after the revaccination. Some authors (12) believe that the complement system is adequately available during early stage of infection not only in blood, but also on bronchial, cervical and intestinal epithelial surfaces as complement activation and subsequent opsonization with $\mathrm{C} 3 \mathrm{~b}$ component are the key events of innate immune system response to infections. In the view of Gabay and Kushner (13), components of CPCA, many of 
which are acute phase proteins, play a proinflammatory role in immunity. It is also reported that $\mathrm{C} 3, \mathrm{C} 4$ and ceruloplasmin exhibit weak and inconsistent acute phase response (14). CPCA results in chemotaxis from one part, exudation of plasma proteins in the inflamed area, opsonization of infectious agents and damaged cells (12-13). On the other side, it is possibly related to its involvement in the development of vaccinally induced antibody responses. The investigations on the role of $\mathrm{C} 3 \mathrm{~d}$ complement component for B-cell activation and regulation of adaptive immunity support this statement (15-16).

ESR is one of the most popular parameters of acute phase response during inflammation. ESR is an indirect index of plasma concentrations of acute phase proteins, especially fibrinogen. It could be however influenced by the size, shape and number of red blood cell counts, as well as by other plasma constituents such as immunoglobulins (13). In this study, ESR was enhanced, most prominently on the $72^{\text {nd }}$ post vaccination hours. Earlier studies (3) reported enhanced ESR, muscle weakness and fever after i.m. application of vaccines containing aluminium hydroxide as adjuvant.

In this experiment, booster vaccination did not cause alterations at injection site except for one animal presented with slight and rapidly resolving oedema. Our data are comparable to those of Singh et al. (17), which have observed no swelling at the site of intramuscular injection against EHV-1. We observed also acceleration of pulse rate (within the reference range) and lack of statistically significant changes in respiratory rate and rectal temperature. Normal rectal temperature, pulse and respiratory rates and substantially increased serum amyloid $\mathrm{A}$ and fibrinogen, decreased serum iron and leukocytosis were established in horses vaccinated against influenza and tetanus (18). Vaccination of horses could be regarded as an ethically acceptable mild inflammation stimulus in investigation of equine acute phase response events, in a way similar to human vaccination (19).

\section{CONCLUSIONS}

Vaccination against EHV4/1 and EIV induces a pronounced acute phase response manifested through increased haemolytic activity of CPCA and enhanced ESR at the background of lack of changes in respiratory rate and systemic clinical signs of inflammation such as fever. It led to acceleration of pulse rate within the reference range.

\section{REFERENCES}

1. Israeli, E., Agmon-Levin N. and Shoenfeld, Y., Adjuvant and autoimmunity. Lupus, 18:1217-1221, 2009.

2. Kichener N., Vaccination Aversion. Health Horse. Canada. May/Juni, 2009. www.horsescanada.com/archives/vaccinatio n-aversion/

3. Gherardi, R.K., Coquet, M., Cherin, P. L. et al. Macrophagic myofasciitis lesions assess long-term persistence of vaccine-derived aluminium hydroxide in muscle. Brain, 124:1821-1831, 2001.

4. Andersen, S. A., Petersen, H.H., Ersboll, A.K. et al., Equine serum amyloid A response following vaccination against influenza and tetanus. $5^{\text {th }}$ International Colloquim on Animal Acute Phase Protein, Dublin, March, Ireland, p.36, 2005.

5. Stokka, G.L., Edwards A.J., Spire M.F. et al., Inflammatory Response to clostridial vaccines in Feedlot cattle. J Am Vet Assoc, 204:415-419, 1994.

6. Chanter, N., Bacterial infections including mycoplasmas. In: Lekeux P. (ed), Equine respiratory disease. International Veterinary Information Services, Ithaca, N.Y. USA, 2002.

7. Wagner, I.P., Rees, C.A.,Duncan R.W. et al., Evaluation of systemic immunological hyperreactivity after intradermal testing in horses with chronic laminitis. Am J Vet Res, 64: 279-283, 2003.

8. Gershwin, L.J., Netherwood K.A., Norris M.S., et al., Equine IgE responses to nonviral vaccine components. Vaccine, 30: 7615-7620, 2012.

9. Orbach, H. and Tanay A., Vaccines as trigger for myopathies. Lupus, 18: 12131216, 2009.

10. Mayer, M., Complement and complement fixation. In: E.A. Kabot \& M.M.Mayer (eds.), Experimental Immunochemistry, $2^{\text {nd }}$ ed, Charles C. Tomas Publisher, Springfield IL., pp.133-240, 1961.

11. Coley, S.C., and Leid, R.W., Effects of extract of Onchocerca cervicalis from horses on the lytic activity of human, rat and equine complement. Clin Immunol Immunopathol, 23,113-123, 1982.

12. Blom, A., Hallström, J. and Riesbeck, K., Complement evasion strategies of pathogens - Asquisition of inhibitors and beyond. Mol 
Immunol, 2009.

doi: 10.1016/j.molimm.2009.04.025.

13. Gabay, C. and Kushner, I., Acute-phase proteins and other systemic responses to inflammation. In: Franclin, H. and Epsstein, M.D. (eds). Mechanisms of disease. $N$ Engl J Med, 360: 448-454, 1999.

14. Stuart, J. and Whicher, J.T., Test for detecting and monitoring the acute phase response. Arch Dis Child, 63:115-117, 1988.

15. Toapanta, F. R. and Ross, T. M., Complement-mediated activation of the adaptive immune responses: role of $\mathrm{C} 3 \mathrm{~d}$ in linking the innate and adaptive immunity. Immunol Res, 36:197-210, 2006.
16. Carroll, M. C., Complement and humoral immunity. Vaccine, 26S:128-133, 2008.

17. Singh, B.K., Tandon S.N. and Virmani, N., Immune responses to inactivated oil adjuvanted Equine Herpes Virus-1 using different emulsifiers in horses. Indian $J$ Biotechnol, 5:42-46, 2006.

18. Andersen, S.A., Petersen H.H., Ersboll, A.K. et al. Vaccination elicits a prominent acute phase response in horses. Vet J, 191:199202, 2012.

19. Verschuur, M., van der Beer M.T., Tak H.S. et al. Interindividual variation in response by fibrinogen, C-reactive protein and interleukin-6 to yellow fever vaccination. Blood Coagul Fibrin, 15:399-404, 2004. 